\title{
تأويل الصمت في أداء الممثل المسرهي العراقي - مسرهية "هذا الذي حدث عندما كنا ننتظر" انموذجاً -
}

م.م. سلعد فافر شبوط

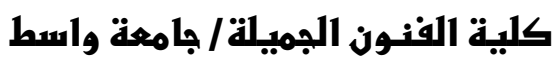

يشكل "تأويل الصمت" ظاهرة يومية متكررة لاى البشر لأنها تمثل لغة تعبير عن الأفكار ودواخل النفس الانسانية الى المتلقي من

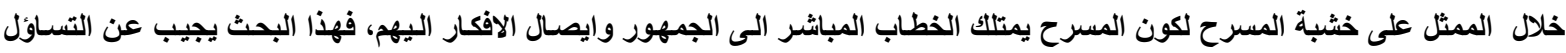

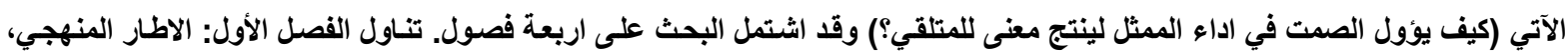

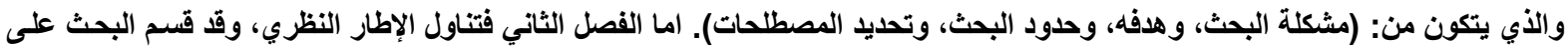

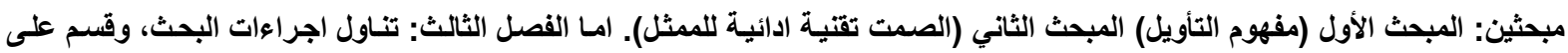

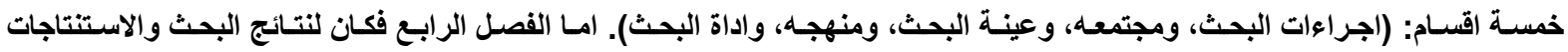

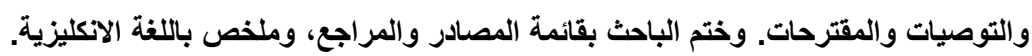

\section{الإطار المنهمبي}

مشكلة البحث: الفن المسرحي، لغـة تجـاوزت المحلية لتخاطب العـالم أجمـع، والصمت لغـة اتصـال بين أفراد المجتمع، للتعبير عن دواخل النفس البشرية. وللصمت رسـالة ذات تأثنير وفاعلية لمـا يحمله الصمت من بعد

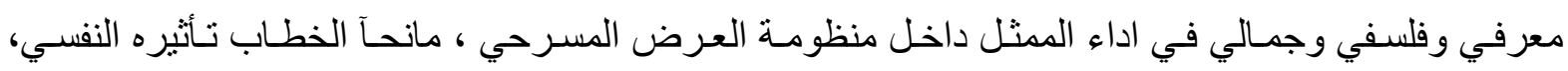
و الفكري في عملية فلك شفرات القراءة والتلقي وصولاً الى عملية كثف الاسرار بالمعاني بعملية التأويل. يختصر الباحث مشكلة بحثه بالتساؤل الآتي: (هل الصمت هو مجرد تمثيل كلمات، او هو عملية لتحريك الوعي من خلال اداء الممثل الصامت وتأويل هذا الصمت الى معان عديدة معتمداً على مهارتهـ وقدرتهـ الادائية على خشبة المسرح. ومن خلال ما تقدم يبرز السؤال التالي: (كيف يؤول الصدت في الاداء لينتج تغيراً بـالمعنى عند

\section{أهمية البمث:}

1 - تكمن اهمية البحث حول دراسـة الصمت وتأويله وتأثثيره على بنية العرض المسرحي، باعتباره احد الوسائل التي يلجأ اليها الممثل المسرحي لإعطاء اكبر دلالة على التعبير عن مكامن النفس وهمومها ورغباتها.

$$
\text { r - - يفيد العاملين بالمسرح و المؤسسات الفنية ذات الثأن. }
$$

هدف البحث: يهدف البحث الى التعريف بأثكال تأويل الصمت الاداء الممثل في العرض المسرحي. 
الحد الموضوعي: دور الصمت كلغة مستقلة في بنية العرض المسرحي وتأويله

تحديد المصطلحات

التأويل لغة: تعني البحث عما هو أول في الثيء (الأول هو الرجوع، وقد آل يؤول اولاً، اي رجع، واول الكلام

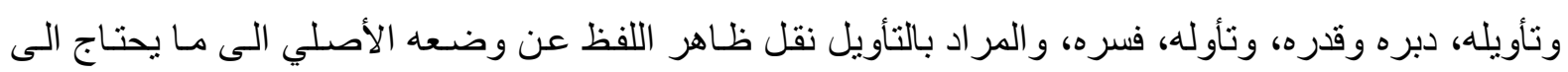

دليل لو لا ما ترك ظاهر اللفظ، والتأويل تفسير الكلام الذي تختلف معانيه و لا يصح الابيان غير لفظه) ('). التأويل اصطلاحاً: هو اجر اء يصرف اللفظ بواسطته الى معاني جديدة مغايرة ، بشكل فاعل يجري خلالها تحويل النص و انتاج المعنى عبر كلام القارئ الذي يغدو نصـاً جديداً مختلفاً عن النص المقروء، هذه الفاعلية ليست ممكنة من دون الكلام، فللكلام ايضاً اثره وفعله، انه يخدع ويلعب من وراء المؤلف و على حسـاب الثـيء الذي يتكلم عنه ، بمعنى ان المنطوق لا يحيل مباثرة الى المرجع، وان النص لا ينص تمامـاً على المر اد. هنـاك

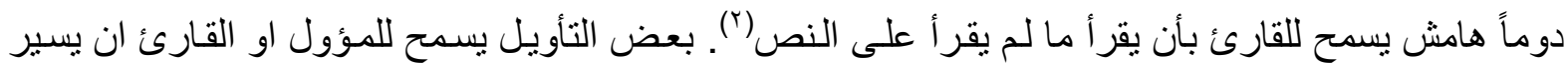
بعداً مجهولاً في النص، وان يكتشف دلالات لم تكتشف من قبل، وان قرأ في النص الاصلي قراءة جديدة لم يسبقه اليها احد والانتقال من الظاهر الى الباطن.

الصمت Silence الصمت المعروف بالسكون كثيراً وردت الاشـارة اليهه في القرآن الكريم للالالة على نفي

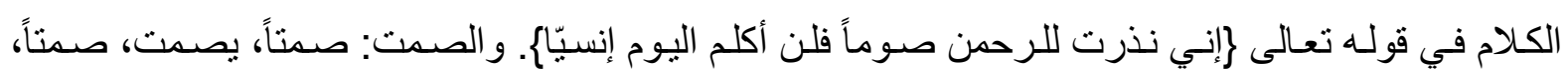

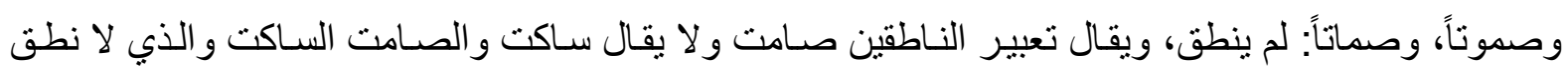

الصمت: الصاد و الميم والتاء اصل واحد يدل على الإيهام و الاغلاق من ذلك صمت الرجل اذا سكت، ويقـال لـه

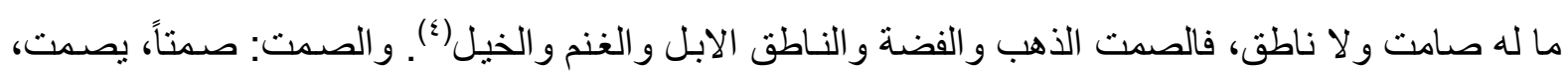

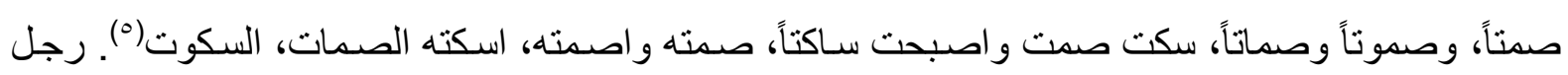
صميت: سكت وزناً ومعنى. وصن.

التعريف الاجرائي للصمت: لغـة بصرية تعبّر عن الأفكار ومكامن النفس من خلال أداء الممثل وتشكيلاته الجسدية على خشبة المسر ح. الاداء: هو سلوك يتم بقدر معين من المهارة في مجال وهو يتطلب قدراً مناسباً من التدريب والاستعداد والتهيؤ حتى يصل المر ع مرحلة التمكن و الكفاءة(؟). الاداء: يعرف الاداء بمعناه اللغوي على انه "كلمة مأخوذة من الفحل أدى ومعناه: أوصل أو قضى، والاداء بفتح

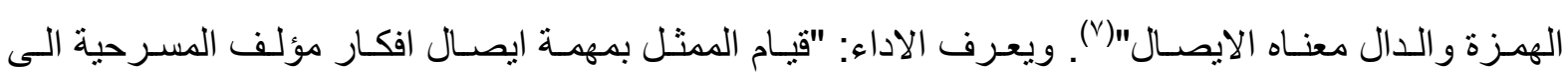

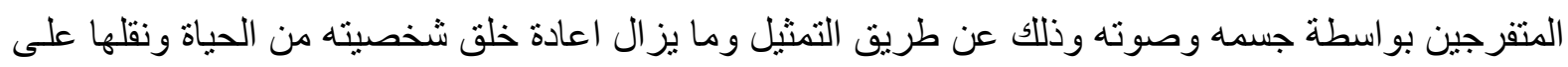

المسر ح بو اسطة هذه الادوات"(^). 
التعريف الاجرائي للاداء: هو سلوك و افعال بؤديها الممثل بوعي في اطار فني على خشبة المسرح بقدرة عالية من الثقافة والاستعدادات العقلية و البدنية و النفسية بو عي.

الاطار النظري

المبحث الأول : مفهوم التأويل

اختلف المؤرخون حول اصول (الهرمينوطيقا) فمنهم من يردها الى المجهودات التي بذلها الاثينيون في العصر الكلاسيكي من اجل استخر اج معنى الملاحم الهوميرسية. في حين يؤكد (جورج غوسندورف) (9** انها تعود الى عشرات القرون وانها بدأت في الاسكندرية، ثم استرجعت في عصر النهضـة والاصـلاح، لكي تزدهر بعد ذلك في عصر الانوار وعصر الرومانسية، وهي في نظره ذات اصول دينية، وقد املتها الحاجة الى تأويل الكتاب المقدس (الانجيل) ولهذا يربط الانتشار الواسع الذي عرفته الهرمينوطيقا بانها البروتستانتية في عصر

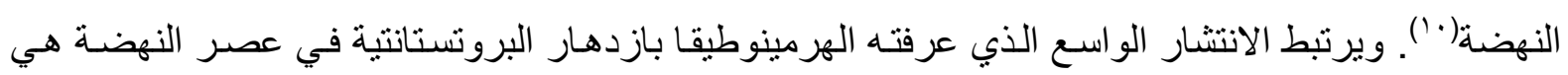

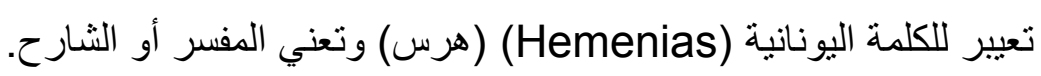
نسبة الى الالهه الاغريقي ابن كبير الالهة (زيوس) و(مايـا) وهو الـه متعدد الوظائف والاختصاصـات و المجالات، ويرمز الى المعرفة الكلية والتأويل الثامل، ورسول الحكمة الى البشر كمـا يرمز الى الكلمـة التي

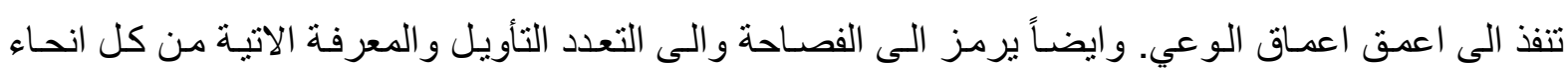

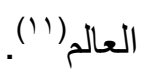

اتخذ المؤول، في الادب، دوما دلالة الوسـاطة، فهو وسيط بين النصوص الملقاة والافر اد الذين يسعون

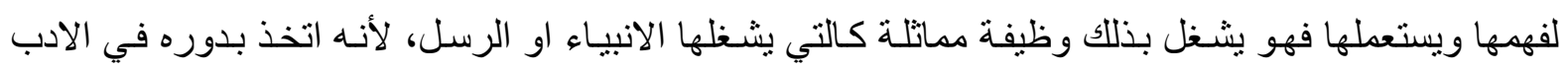

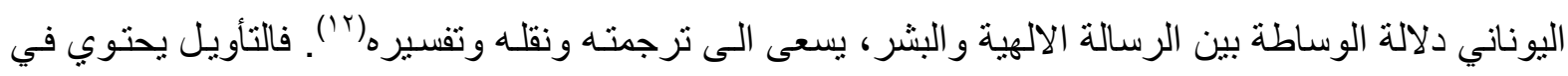
مدلو لاته على ضروب ثناثة من المعاني: في المعنى الأول تفصح هذه اللفظة عن فعل التعبير والقول و البلاغـة، وفي المعنى الثاني تفصح عن فعل الثر ح والتفسير، وفي المعنى الثالث تفصح عن فعل الترجمـة والنقل استناداً

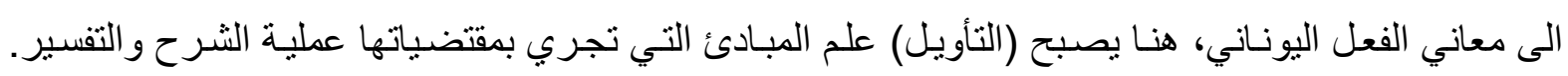

$$
\begin{aligned}
& \text { بمعنى ان التأويل بأتي بثلاث معاني. } \\
& \text { 1ـ التعبير (نطق) الكلام - ترجمة. } \\
& \text { r- تأويل (تفسير ايضاح). } \\
& \text { r- ترجمة (نقل، تعويض الالفاظ). }
\end{aligned}
$$

استخدم اليونان التأويل بمعناه التفسير على الاساطير والثعر و الفلسفة، والفلسفة للاجابة على التسـاؤلات

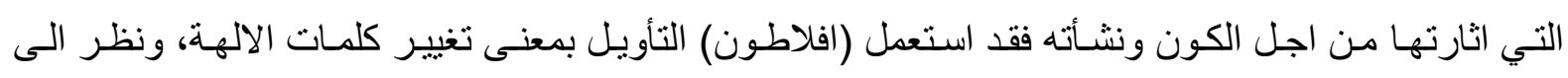
الثعر اء على انهم مفسرون ومترجمون للالهة، اذ تعد محساورة ايون من اهم المصسادر التي نهل منها اعلام الهرمينوطيقا، وتعود اهمية المحاورة انها ارست الدعائم الاولى للادوار التي يلعبها المؤلف والقارئ وسلطة 
النص في البحث عن المعنى والقيمة والانسان. بقوله على لسان (سقراط): "ان فهم هوميروس ليس مجرد حفظ

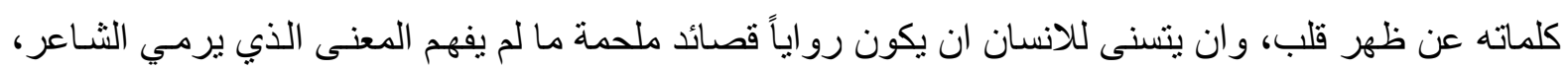

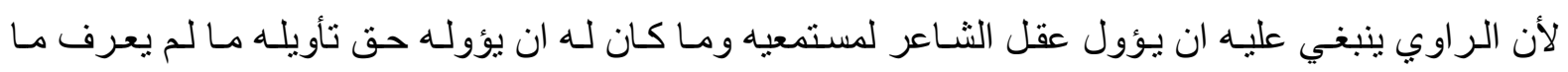

وبهذا ارتبط التأويل عند افلاطون بالثعر والرواية من جهة المعنى وهو الامر الذي يتطلب الاتقان في

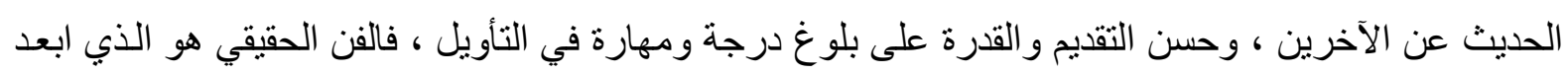
عن التمويل وقريباً من الفن و الجمال و الخير، و المؤول له درجة الفيلسوف و وانه يرتقي الى مرتبـة الحكيم ويكون

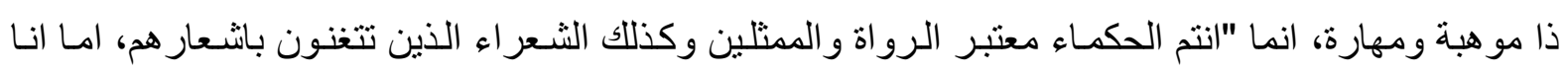

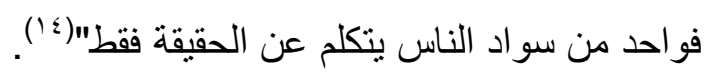

ارسطو:

خالف ارسطو استاذه (افلاطون) في كون الثـعر يحاكي الطبيعة محاكاة خالقـة (ابداعية)، فان الطبيعة

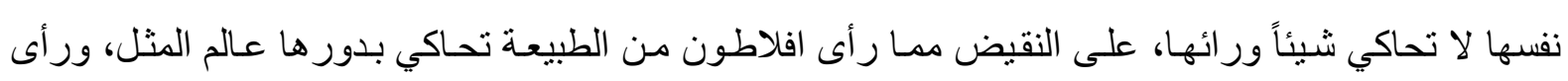
ارسطو في المحاكاة لما يجب ان تكون وليس بما هو كائن وهذا الاتجاه يعطي الفن قدرته على الابداع والخلق وفي تفسيره للفن ذو صفة تأويلية ـ "ان المحاكاة في الفن ليس محاكاة للجمـال المثالي كمـا يقول افلاطون و وانما تقدر قيمة المحاكاة بمقدار ما تبعثه من رضا ومن بهجة في نفوس المتذوقين للفن" (10").

تحديد ارسطو لمعنى المحاكاة في الفن و الثـعر على وجه الخصوص - كان اشـارة منه لتعدد معانيها بحسب السياق الذي ترد فيه، ولعل اهم اضافة كانت في قصدية المحاكاة كونها ليست نتيجة للو اقع بل انها الطبيعة بمـا

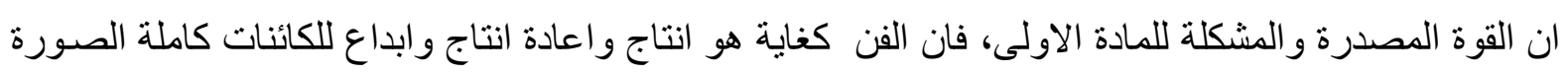

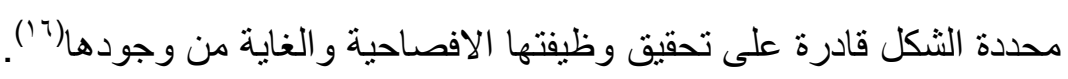

التأويل في الكتب السماوية

انبثق التاؤيل من الكتب المقدسة التي تعني فن تأويل الكتب المقدسة ولاسيما النصوص المقسسة وكتب اللاهوت. و التأويل في الديانة المسيحية تأثرت فكرة التأويل الحرفي ـ المجازي في تفسير النص المقدس و وعلى ندي هذا ظهرت مدرستين للفكر داخل الكنيسة. المدرسة الاولى في الاسكندرية والثانية في انطاكية، ويقوم التفسير لدى الاولى على ان لغة النص الديني رمزية ويجب ان تفهم بطريقة تأويلية، اذ كان الايمان بان المسيح (الكلمـة) يتكلم في العهد القديم كما يتكلم في العهد الجديد، اما المدرسة الثانية فان المفسرون يتبعون التقليد اليهودي المحلي في التفسير، اذ كان التركيز على بلى الته

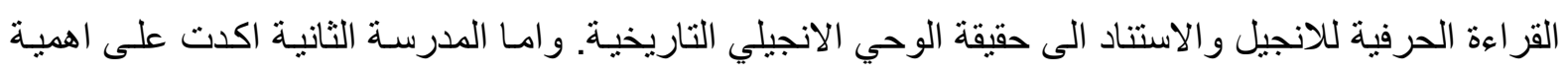
اعادة النص المقدس حسب تعاليم المسيح- بمعنى ان التأويل الحرفي انه معنى تاريخي، فقد بـات من الضـروري ولئي

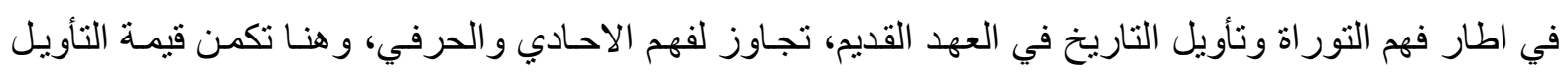

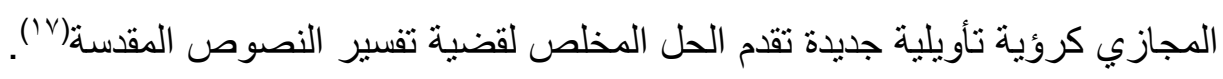


إذ يتضح في بداية حياة الكنيسة الاولى أن الهرمينوطيقا وظفت ـ الاول معني بتجديد القراءة الكتابية في

ضوء حدث المسيح اي اثبات نصوص الثـهادة الانجيلية التأسيسية في امتداد نصوص العهد القديم، اي اعـادة

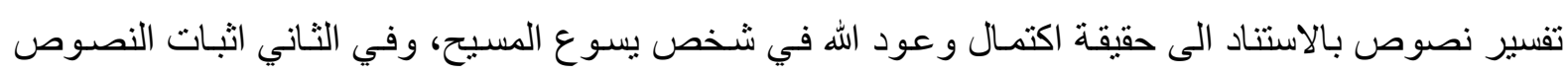
الجديدة نصوص الثهادة جعلت هذه النصوص المسيح هو المرجعيـة الروحيـة العالمـة لانـارة وتفسير الكتب في في لئي العهد القديم.

مفتاح التأويل في الكتاب المقد لانه موجه لخلاص الانسان لذلك فهو على غرار الانسان:

$$
\begin{aligned}
& \text { - جسد (المعنى الجسدي = التاريخ) } \\
& \text { - - نفس (المعنى النفسي = الاخلاقي) } \\
& \text { - ـ ـ روح (المعنى الروح = الرمز والارتقاء الى المعنى الروحي). }
\end{aligned}
$$

فهو يتحدث عن دلالتة ثلاثيـة للنص المقد، معنى حرفي ومعنى نفسي ومعنى روحي حسب درجات الناس وطاقة عقولهم.

"ان ارتباط فن التأويل بالمذهب الذي تنتمـي اليه النصـوص المقدمـة ممـا دفع احد الاصـلاحيين (مـارتن لوثر)(^/*) الى الثورة على سلطة الكنيسة في مسألة مصادرة حرية قر اءة النص المقدس ليقترح اولويـة التراث في تأويل بعض المقاطع الغامضة من النص وطابع الاستقلالية في فهم محتوياته بمعزل عن الاخر او التوجيـه القسري"(19).

و هذه المواجهة لسلطة القراءة الاحادية بوصفها المبدأ الاساسي للنظرية فن التأويل الحديثة. اعطى القر آن الكريم بجلال بمنزلـة التأويل واعطاهـا من الفضل والكمـال المنزلـة العظيمهة، وقد وردت كلمة (التأويل) في عدة سياقات قرائية، لكل واحدة منها خاصية معينة، تضفي على اللفظة بعداً يختلف عن سياق الآخر الذي يحتاج النظر والفكر، وذلك بصرف معنى الآيـة عن ظـاهر لفظها الى معنى آخر يحتمله السياق بالدليل و القرينة والا اصبح المعنى محالاً، يورد الباحث بعض الايات القرآنية التي وردت في لفظة (التأويل).

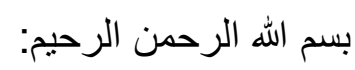

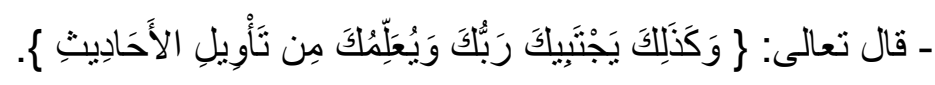

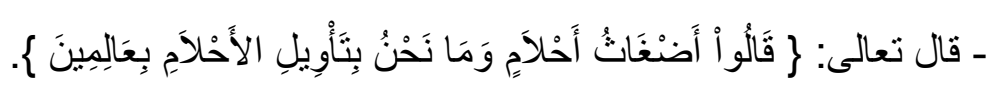

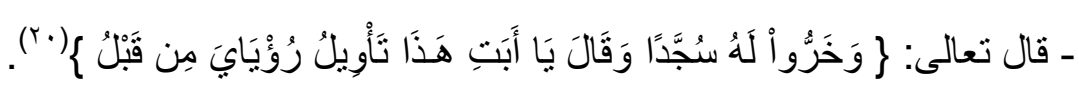

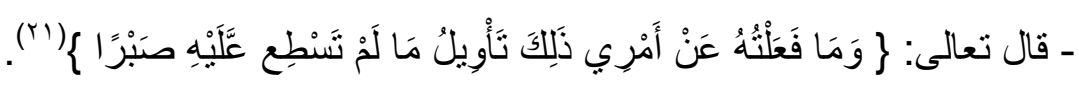
تللك الآيات تعكس مفهوماً واسعاً للتأويل احتمل التفسير و التعيين و العاقبة و المصير ووقوع المخبر عنهـ وتعبير الرؤيا ومدلولها وتأويل الاعمال، وبيان السبب الحاصل عليها كلّ حسب سياقه ودلالته. 
التأويل وسيلة لغاية الفهم لا يفهم المفسرون الا بعد ان يؤول، ولا يكون التأويل الا اذا يذهب السند عنه ، فاذا ذهب عنه يطرح سؤال استفهامي اي سؤالا بانقطاع السند فكل انقطاع في الراوي ينوقف الو اقع التاريخي. يتوقف المفسرون امام النص يحاولون استتطاقه وذلك بتبديل الجملة الصـامتة بجملة ثانية أن المؤرخ او الباحث يضطر الى التأويل عند انقطاع السند، فأن موقف الأصسوليين الأسـاميين من التأويل هو موقف من لا لا

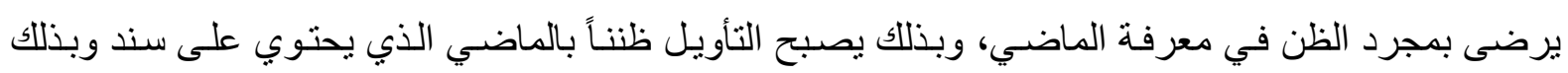
يكونون ر افضين للتأويل.

وموقف الطرف الآخر من المسلمين المفسرون الاخذين بالتأويل أدى الى نتائج هزت المعرفة اليقينية بالتاريخ اي ان اشكالية الفهم تحولت الى التأويل.

وبهذا التعارض في النظرة الى التأويل فمنهم من ير اه معرفة ظنيـة لأنها يستند الى معرفة غير موثقة (مقطوع السند). و الطرف الآخر يراه معرفة كلية فالتأويل ضرورة للفهر. المبحث الثاني : الصمت تقتية ادائية

يعد المسرح من أهم الفنون وذللك لانه يتجه نحو تصوير الحياة بكل اتجاهاتها، منها الاجتماعية والثقافية و الاقتصـادية والفكريـة والسياسـية والنفسيـة، أذ يهتم المسـرح بتصـوير الواقع ويبحـث عن المعالجـة لمشــاكل

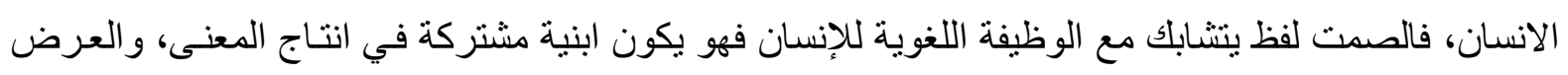
المسرحي يكون فيه بنية سمعية وبنية مرئية تتكون بالعلاقات البصرية "العلاقات التي يستقبلها المتلقي كونها

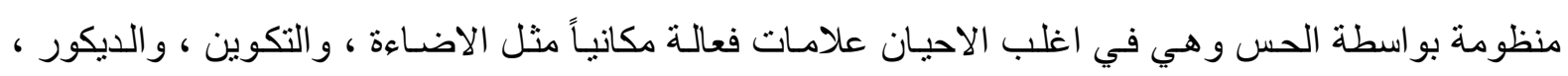

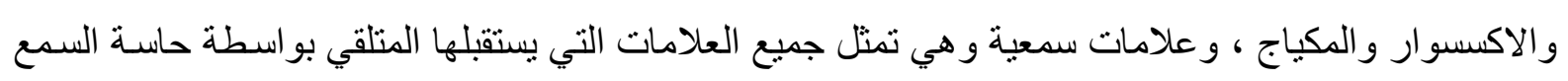

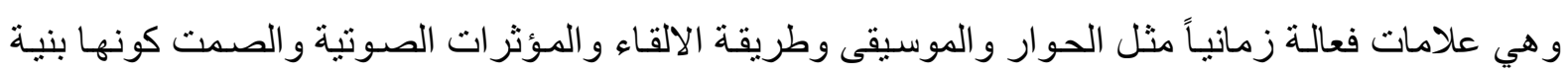
دالة"rr).

فالعرض المسرحي هو ليس نصاً وجود لان الممثل هو الثخصية الحية التي تظهر الصمت بأدائها من خلال صوتها وجسد من حركة وايماءة واشارة، وذات فاعلة مع الملحقات الديكور و الملابس (الازياء) و الخ. وبهذا يعمل بانسجام في الثكل و المضمون ويستخدم الوسائل الر افدة. ان النص الادبي المكتوب يتحول في العرض الى خطاب مرئي بالوسـائل البصرية و السمعية، وبذلك يخضع لتحو لات في الخطاب التأويلي بمظهره الباطني و الظـاهري لانتاج المعنى، ومن تقنيات الممثل جسده

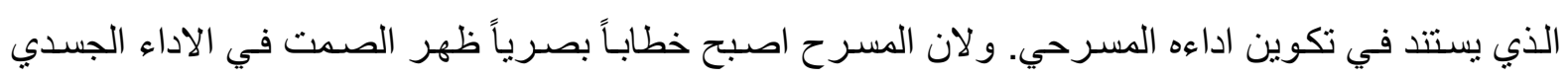
للممثل ، أذ يتركز الصمت في تقنية الاداء من حركة واشارة وايماءة وبذللك يتأول الصمت في النص المسرحي الى خطاب تقني للمنجز الفني (العرض).

اللامعقول اتجاه ادبي جاء نتيجة ظروف قاسية وخصوصاً بعد الحرب الكونية الثانية ليشكل نمطاً ابداعياً في جو انب الابداع الانساني، ظهرت عدة اتجاهات مسرحية منها مسرح اللامعقول. ومن اسباب ظهوره عبثية 
حياة الانسان وخو ائها، والثك في القيم والمبادئ الانسانية، اللفظ من العالم البرجوازي و عالم الحروب و العجز عن الاجابة على اسئلة العصر - و اوهام المجد الزائف، و وانسحاق الانسان في مواجهة المؤسسات القوية. قد فصل الانسان عن دينه وعن روحه واصبحت افعاله عبثية لا معنى لها وهذه النظرة قادت الى نتائج

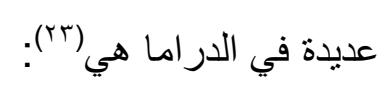

( ) الابتعاد عن نسق العلاقة المنطقية السبب و النتيجة.

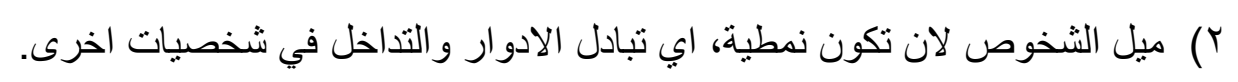

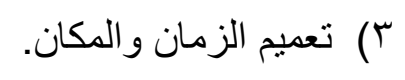
؟) اللغة ثانوية الاهمية اي تشويه اللغة.

0) تستعمل المرئيات بشكل استعاري او رمزي تعويضاً عن اللغة كوسيلة اتصالية. 7) تختفي الفوارق بين الصيغ الدرامية المختلفة يصبح الجدي شاذاً وكوميدياً (غروستاك). ( احتو ائه على الصمت كلغة معبرة عن دو اخل الثخصية.

ان رؤية العبثية عدمية قائمة للوجود الانسان تتخذ مسرحية (انتصار كودو) ل صمويل بكت التي تعتمد على الادر الك و على الحدس و التأويل والصمت فهي تبحث عن الوجود بين الحقيقة و الخيال ـ و وهي من مسرح

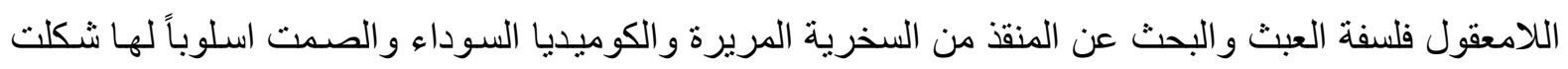
الجو العام لنص الخطاب. فلاديمير : فلتبقى خاصة، تعرف جيداً اني لا استطيع احتمال ذلك. استر اجون: اتساءل احياناً ما اذا كان من الافضل لنا ان نفترق. فلاديمير : لن نذهب بعيداً، يكون ذلك سيئًاً جداً (صمت). - استر اجون: الانرى ان ذلك سيكون مدنباً جداً (صمت). اذا اخذنا بالاعتبار روعة الطريق (صمت) وطيبة المسافرين (صمت)

$$
\text { (صمت) يبقان جامدان }
$$

- استر اجون (صمت ضعيف) لسنا مقيدين (صمت) السنا - فلاديمير : اقسم باني سمعت صر اخاً. - استر اجون: ولماذا عساه يصرخ (صمت)

فالصمت مرتبط بالتفكير، و اذا كان الانسان صامتاً فانه يفكر (انا صامت فانا افكر اذا انا موجود) وحيث وضع ديكارت عبارته المعروفة (انا افكر فأنا موجود). 
الجسد هو من عناصر العرض البصري الذي يساهم في رسم جمالية العرض المسرحي بسهم في تأويل

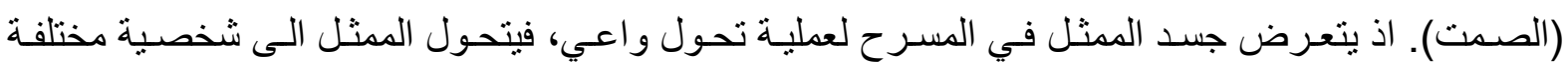

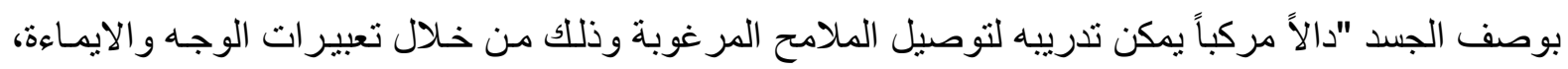

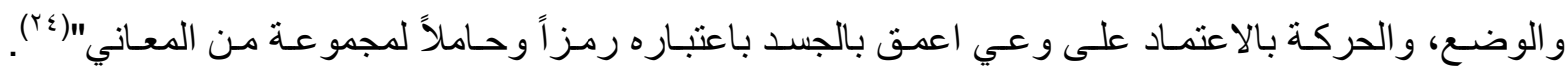

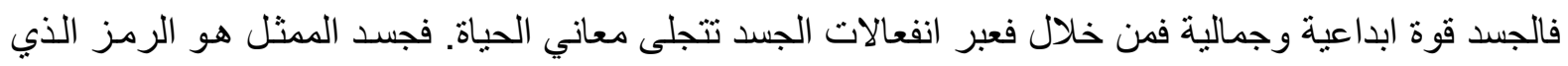

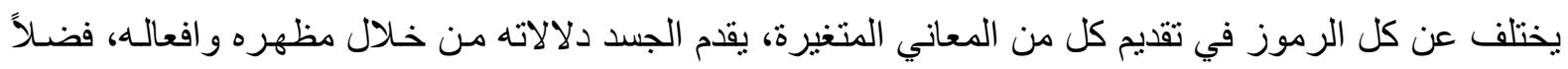

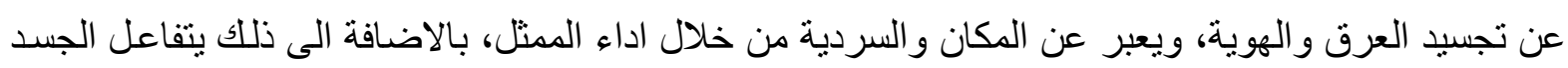

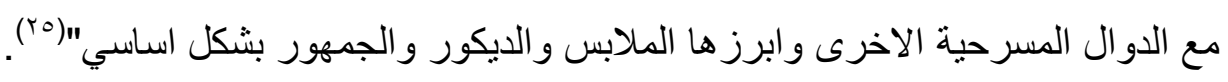
فحركة الجسد (الممثل) ليس مجرد وسيلة انتقال من مكان الى آخر ، وانما هي لغة لترجمة الانفعالات

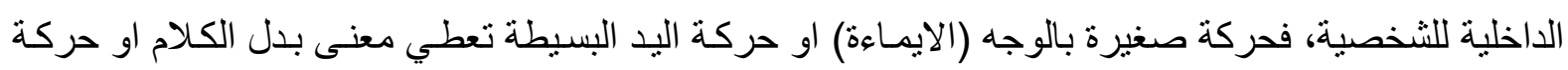
صغيرة بالرأس لها دور في توضيح المعنى و التعبير عن المشاعر.

يرتكز العرض المسرحي على ثلاثة مرتكزات يشكل فيها المثثل احد اهم هذه المرنكزات وهو حلقة

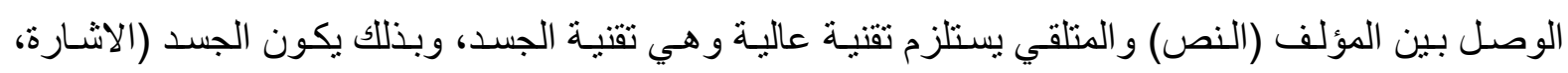

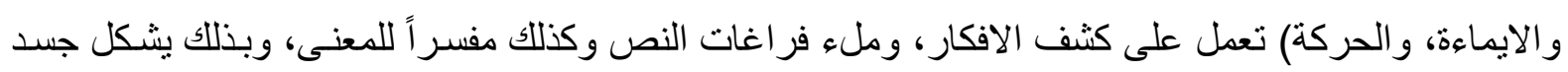

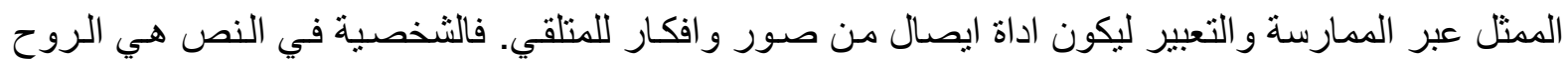
فهي تبحث عن جسد تتحرك من خلاله و الممثل هو ذللك الجسد.

فالثخصية في النص هي الجسد فهي تبحث عن روح تتحرك فيها والمثثل هو ذلك الروح لتجسيد الثخصية على خثبة المسرح فحركة الجسد هو نثكيل جوهر العرض.

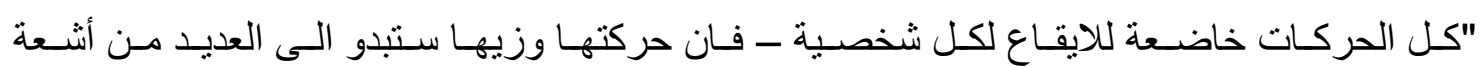
وضياء" (r)

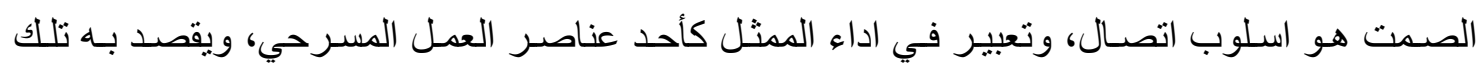

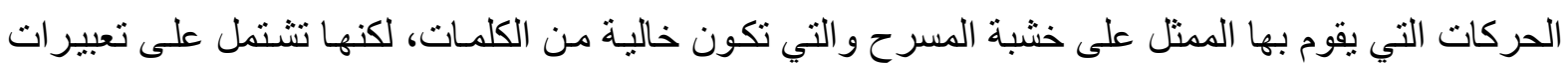

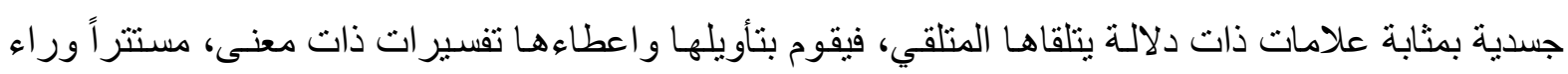

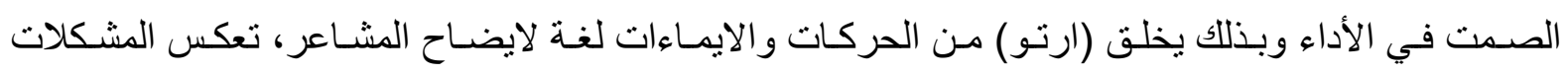

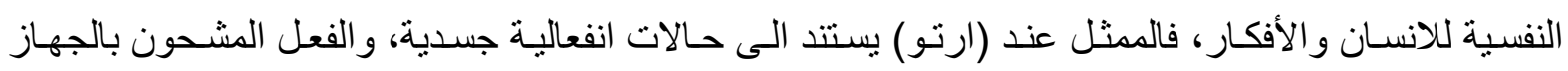

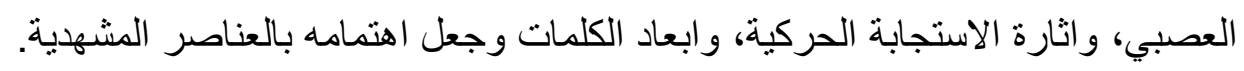
أذ كان يدرب ممثله "على همهمات ولغة مبهمة ولغة سحرية.. و التعبير بالاشكال وكل ما هو حركة"(YV)". أما (كروتوفسكي) الذي او غل في التجريب على الجسد، إذ لجأ الى مصادر عديدة نحو الثرق، منها

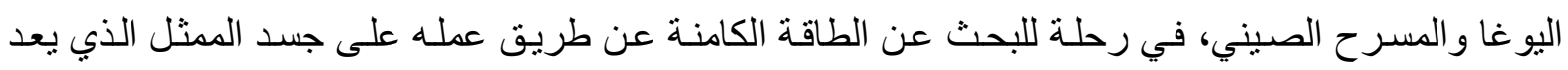


جوهر المسرح من خلال تكوين علاقة الممثل بالجمهور مباثرة، والحركات ذات الدلالة المتعددة عنوانـاً اساسياً للمثل لايضاح رغبات الثخصية و عو اطفها و افكار ها عن طريق الحركات الجسدية والايمـاءات "المسرح يجب ان يذهب الـى مـا ور اء الادب ليكثـف لغتـه الخاصـة و التـي ليست لغـة كلمـات، ولكن هدف النبض الانسـاني

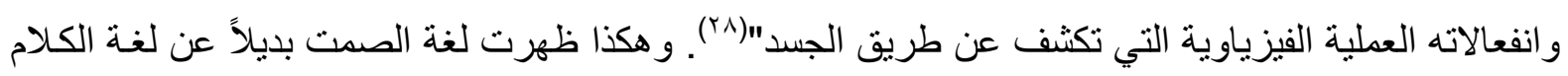

$$
\text { من خلال جسد الممثل وهذا ما اتجه اليه مسر ح الحداثة وما بعد الحداثة. }
$$

نحو زيادة التجريب في تقنية الممثل و الفضـاءات المستخدمة مشهدياً أمثنال (ريتشـارد فورمن) المسرح المفتوح (المسرح الحي) ابتعد عن الخطاب اللفظي، فأداء الممثل الصامت يتبنى ايماءات و اشـار ات جسده وهذه الايماءات و الاشار ات و الحركات على الممثل ان يطور ها وتكون ذات معنى نابعة من داخله، ذات بنـاء در امسي، و الذي يعبر عن الأفكار والصر اع أذ تحمل في طياتها معاني ودلالات للكثف عن اللامرئي لجسده مرئياً والذي

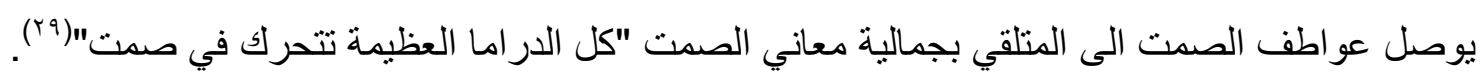
الصمت لغة وتحتوي هذه اللغة ثلاث لغات: ا. ل لغة الاشارة والايماءة: وهي ما ينظمه الممثل من اشارات وايماءات. r. ب. لغة الحركة: لغة حركة الممثل وهي اما موضعية او انتقالية. r. . لغة ملحقات العرض مع الممثل: فهي كل مـا يتعلق بالممثل و عناصر العرض المسرحي (ديكور وازياء و اكسسو ارات وموسيقى وضوء).

تعتمد هذه على لغة الجسد ويتم التو اصل فيها عن طريق القناة البصرية، وتعطي معاني عديدة بحسب مغزاها، فالعملية الاتصالية تبدأ من عنصر المرسل وتتتهي بعنصـر المستقبل مروراً بالرسـالة وقناة الاتصسال مبنية على اساس الفهم الصحيح من فبل المرسل والمرسل اليه. فـالعرض المسرحي هو اتصـال يلعب الممثل فئل الدور الرئيسي في ايصال رسالة العرض من خـلال الايمـاءة والاشـارة و الحركة، أي ان هنالك اداء متقن مبدع لكي بستطيع توصيل الفكرة وبثها والحركة لغة تعبر عن نفسها من خلال الجسد في الحياة.

اما في المسرح فتعد حركة الجسد علامـة من علامـات الخطاب البصري، فجسد الممثل سطور ممتلئة بالكلمات تحتوي على معنى ليقوله، لأن الكلمات خرساء، لا تعبر عن الحقيقة لذا "معاني الكلمـات الحقيقيـة هي

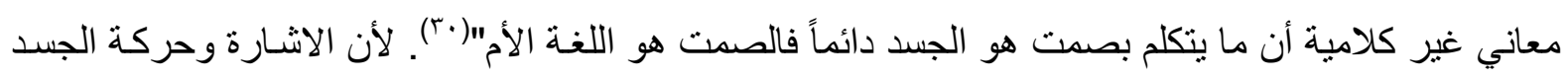
اكثر بلاغة واصدق من الكلام لانها نابعة من النفس خلجاتها وانفعالاتها، و الحركات قد تسبق العلامـات و لأنها

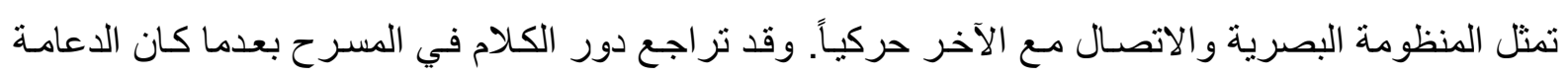
الاساسية، أذ كان المسر ح يعتمد على الخطاب اللفظي، فالممثل استطاع من خـلال جسده، ان يحقق الخطـاب البصري. 
المتلقي يكون اكثر متعـة عن طريق جماليات العرض المسرحي البصري، بوجود الفكرة والموضوع و المضمون، والممثل الصـامت بلغنة جسده وتثكيلاته يصل الى تكوين صورة مقنعـة يتذوقها المتلقي بجمالية فيكون الصمت احد اساليب الاتصال المسرحي، يمكن الاشتغال عليه.

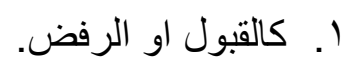

$$
\begin{aligned}
& \text { r. تعبير عن الافكار والانفعالات الانسانية. } \\
& \text { r. استخدامه كفاصل بين الرسالة. }
\end{aligned}
$$

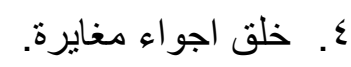

$$
\begin{aligned}
& \text { ๑. استخدامه للتعبير عن الاعجاب او عدمه. } \\
& \text { 7. . التعظيم و الاحتقار. }
\end{aligned}
$$

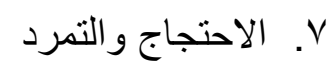

تأويل الصـت علامـة على خشبة المسرح، اثنـاء العرض المسرحي تسـاهم في تفعيل علاقـة المرسل

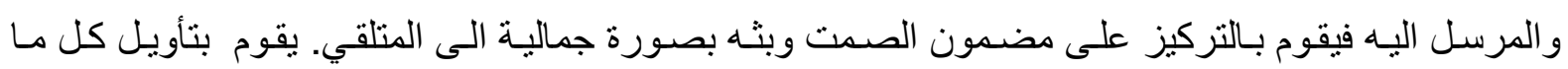

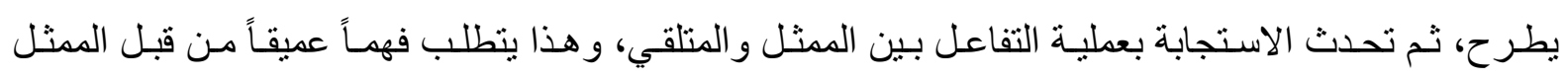

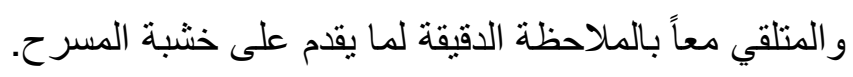
الاراسات السابقة من خـلال التقصـي الذي اجر اه الباحث وجد اطروحسة الدكتور اه بعنوان (تأويل الصـمت في نصوص مسرح اللامعقول) للباحثة سافرة ناجي في تخصص الادب والبر النقد. ما أسفر عنه الإطار النظري ا. التأويل يعتمد على ثقافة المتلقي من استخر اج المعنى من اللفظ او الجسد. r. التأويل عامل مهم ليس لاظهار الحقيقة ولكن الوصول اليها. r. لغة الصمت ابلغ من الكلمات وتأثير ها على المتلقي. ع. تأويل الصمت يعتمد على اظهار قدرة الممثل وتحكمه بجسده.

0. ت تأويل الصمت في اداء الممثل يعتمد على ثقافته وو عيه.

7. تأويل الصمت في اداء الممثل اقتحم الحياة الداخلية النفسية والروحية. V. V. . الصمت احد الوسائل التعبيرية في المسرح يعطي شكلاً جمالياً للعرض من خلال الاداء المتقن. ^. الصمت ثورة على الكلمة في عصر اختفت فيه القيم. 9 9. الصمت سمة من سمات العروض الحديثة وخاصة المسرح اللامعقول.

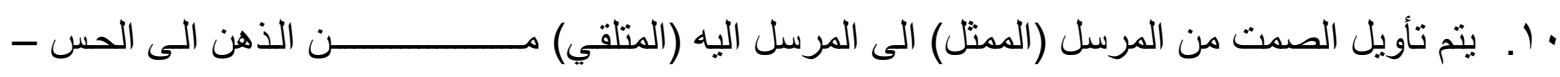
اجراءات البحث 


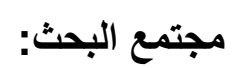

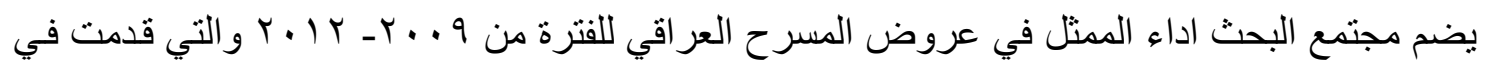

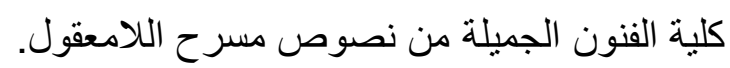

\begin{tabular}{|c|c|c|}
\hline المخرج & المؤلف & المسرحية \\
\hline اركان محمد & اوجين يونسكو & l. الجموع والعطش \\
\hline علاء قحطان & جان بول سارتز & r. اللّه والثيطان \\
\hline علي كريم & صاموئيل بكت & r. في انتظار غودو \\
\hline صارم داخل & صاموئيل بكت & ؛. هذا الذي حلث عندما كنا نتنظر \\
\hline عبد الكريم عبود & اوجين يونسكو & 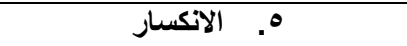 \\
\hline
\end{tabular}

اداة البحث: اتخذ الباحث من المؤشرات التي اسفر عنها الاطار النظري اداة للتحليل. وسائل البحث:

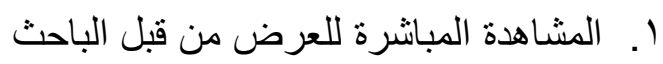

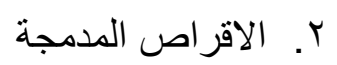

عينة البحث: مسرحية هذا الأي حدث عندما كنا نتنظر مقتبسة من مسرحية (في انتظار كودو)

$$
\text { تأليف (صموئيل بكت)... إعداد وإخراج: د. صارم داخل }
$$

فكرة العرض: تبنى فكرة المسرحية على الموقف الإنساني من الركود، و الركود يينى على فر اغ هائل بتمثل في الانتظار غير المجدي. فالمسرحية تصور الفراغ الذي تعانيه كل شخصية، فأبطال المسرحية ينتظرون (غودو) ويلحون بالانتظار، ولكن غودو لـ بـأتِ وهو لن يأتي، فـإن الاتتظار نسيج المسرحية، والقلق هو المضمون الدقيق للانتظار، و المسرحية تكثف عن قلى الانسان حينما ينتظر مجيء منقذ إذ يهب للحياة معنى ويضـع حداً

$$
\text { الآلامه وفي النهاية لا يأتي ومن ثم لا يوجد معنى. }
$$

1 ـ شخصية الجنر ال: يمثل السلطة.

r ـ الفتاة الثابة تمثل الحياة والأمل.

ب - فلاديمير يمثل انتظار (المخلص)

ـ ـ ستر اغون: يمثل البحث عن المنقذ. 
ه - بوزو: مالك متسلط.

7 - لاكي: شخصية تابعة ليس لها إر ادة.

الفضاء: قسم الفضاء على مستويين:

المستوى الأول: عمق المسرح الذي يمثل الماضي

المستوى الثاني: مقدمة المسرح التي تمثل الحاضر

فإن الاهداف تأتي من الماضي و انعكاسها على الحاضر

الروية الإخراجية: اعتمد المخرج على الكثف الواقع عن طريق الفعل الإنساني على أسـاس اعطاء ذللك الفعل أقصى طاقة للاشتباك بين ما تريده الثخصيات وبين قصد المخرج في الانتظار و الكثف عن وجودها الحقيقي. تحليل العرض: يبدأ العرض المسرحي بإضاءة خافتة ومن ثم يظهر ساتر حربي يتكون من أجساد الممثلين على شكل بناء هرمي يمثل ثكنة عسكرية وفي وسط الثكنة (علم).

تتحرك الثخصيات على شكل مجـاميع باتجاهـات مختلفـة، ويكون اداء الممثلين معتمداً على الأداء الصامت يعززه الموسيقى التي تخلق جواً يحيلنا على الموقع العسكري، إذ يعتمد الأداء خطاب الصمت وخطاب الجسد و الحركة والاشارة، وتظهر شخصية (الجنرال العسكري) يرتدي بزة عسكرية يتحرك بمسير عسكري منضبط بمصاحبة الموسيقى العسكرية الذي يمثل السلطة والسبطرة، ومن ثم يلقي ابيـات شعرية ومن ثم يقوم بحركات تتذر بالحرب والصر اع تدل على صر اعه مع ذاته، ويؤول عن الانسان المستلب ومدى انسحاق الفرد امام متاريس وسو اتر الحرب والسلطة وضياع الانسـان. ومن ثم تدخل شخصية (الفتاة الثـابة) تحمل في يدها وردة تقدمها الى (الجنر ال)، وترمز للأمل و المستقبل الذي يقوم بفرض وض وذه وده الوردة.

و المجتمع العر اقي في موروثه تعاطى كثيراً مع فكرة الغائب الذي تتنظره المجموعة من اجل ان يؤسس لهم معنى في تثبيت قو اعد العدالة الاجتماعية وبما يذهب عنهم كل قلق قد يخدش وجودهم مثلمـا يخدش عدالة وضـعهم في التعايش والسلوك. ويدور حوار بين (الجنر ال) و(الفتاة)، يتخلله صـر اع معزز بلغـة بالحركات و التكوينات الجسدية معبر اً عن صر اعه الداخلي وما يحل به من ويلات الحرب ومن ثم تدخل الثخصية الثالثة (فتاة) أكثر عمراً حاملة في يديها كتاب تتقدم الى أن تصل الى وسط المسرح، وتقوم بتمزيق الكتاب ونشره على ونى خثبة المسرح، والذي يمثل التاريخ. وتقوم (الفتاة الثـابة) بجمـع الأوراق ومن ثم ينسـب الممثلون من خشبة المسـرح. إذ لجـأ الممثلون الى استعمال الخطـاب اللفظي، و الخطـاب الصـوري، الاشـارة و الحركـة والإيمـاءة).

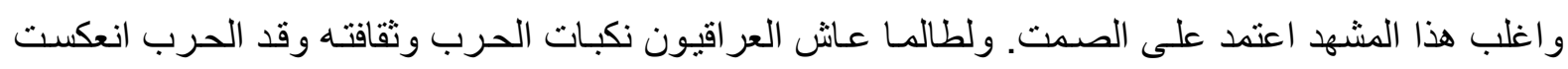
التقافات على طريقة تعاملهم اليومي فضلاً عن أنها انعكست على طريقة ادائهم الفني، في المسرح فضلاً عن ان رؤية المخرج تأثتث بأثاث حربية كان الخطاب و التفاعل المنضوي في تفاصبل العرض المسرحي وصو لاً الى لى اداء الممثل المسرحي كانت جميعاً نأثرت بذلك الخطاب مما اعطى دقيقاً للهروب من الحرب عبر ايجـاد مسـاحة 
من الانتظارن او ايجاد مساحة من الانتظار الذي يقصد به الممثل لحظة ادائه بوجود سلطة عليا تدفع بـه في كل مر احل حركاته حياته ، انفعالاته نحو الانتظار من جهة، ونحو تشديد او وحشية السلوك من جهة ثانية.

تدعونا الحرب الى هزيمة أنفسنا، الدخول في مستتقع الخسار ات، ونسمع الكثير من الصر اخ الداخلي إذ تستفز الصيحات تلك الصيحات الداخليـة التي ترفض بها الحرب على امل ان نتمسك بقادم ينتشل ايادينـا من هز ائمنا النفسية، او الوجودية وهذه كلها ثقافات متداخلة عبر التاريخ، فهي فضلاً عن سلوك نعيشـه كل يوم هي مدونات تاريخية شملت اجيالاً مختلفة كانت تعاني بمثل مـا نعانيه اليوم. ومن ثم تظهر شخصية (ستر اجون) وشخصية (فلاديمير)، وهم وحدهم يتو اصلون لفظياً او بصمت، ومن ثم تبدأ الثخصيتان بالصر اع مـع بعضـهما عن طريق حركات استعر اضية توحي بالصدام و العنف، و اعطاء كل حالة معنى معين ومختلف عن الاخر لـه له دو افع لتحريك عجلة الأحداث و الأفعال، و الذي توضـت فيهـ ملامسح الدمار و الضياع و هلاك الإنسـانية، وعن طريق شخصية (فلاديمير) الذي يمثل حالـة الانتظار في وقوفه في وسط المسرح، أمـا شخصية (ستر اجون) تدور الثخصية حول المسرح تمثل حالة البحث و الضياع والقلق من عدم مجيء المنقذ. وعن طريق حركة الثخصيتين المستمر، و الخطاب اللفظي يتو اصل مع المتلقي بإيصـال فكرة الحرب، وما تفعله من دمار وتعاسة الإنسانية، وان مصير الإنسـان الموت، والمتمثل في شخصية فلاديمير عن طريق بـ فيق وقوفه على خشبة المسرح على شكل (صليب)، ويكون الاداء صمت، وهو إثشارة لخيبة الامل في نجاة الإنسـان من الدمار. وشكل الصليب هو قصة تعذيب المسيح وأيامه الأخيرة، ويمثل لحظة قدوم المسيح الى اليهود الذين كانوا ينتظرونه، ولكن عندما جاء لم يتعرفوا عليه ولم يعترفوا به. هذا في نص (لبكيت) الاصلي. استر اجون: قال جودو

فلاديمير: لا أبداً

استراجون: الى بوزو، الست السيد جودو يا سيدي؟ بوزو: انا بوزو، (صمت) الا بعني لكما هذا الاسم شيئً؟ (صمت)، قلت: ألا يعني هذا الاسم لكما شيئاً؟. فلاديمير وستر اجون يتظاهر ان بالبحث.

و هكذا يكون فعل الثخصية ومجمـل الحركات داخل فضـاء العرض المسرحي يكون على أسـاس مـا تصر ح به الأحداث من مشكلات، وهموم، وأوجاع، وبما يجعل اداء الثخصية عبر الدور الذي يتحمله الممثل

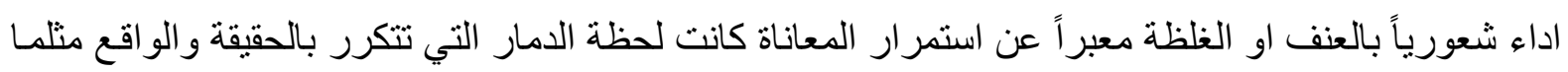
تتكرر عليه بالافتر اض الفني، و هذا هو ما كسبه عبر سلسلة الاحداث التاريخية التي خرجت عليه من مصسادر و عيه الآن، او مصادر لاو عيه الجمعي عبر التاريخ ربمـا اندفع كل ذلك ليعطي للممثل تصور اتل الأداء فضـلاً عن أسلوب او طريقة الأداء. 
ومن ثم يقوم (فلاديمير) بحمل (ستر اجون) على ظهره، و القيام بحركات طفولية تحيلنـا الى الماضـي إذ

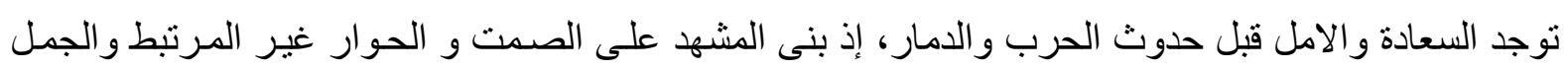

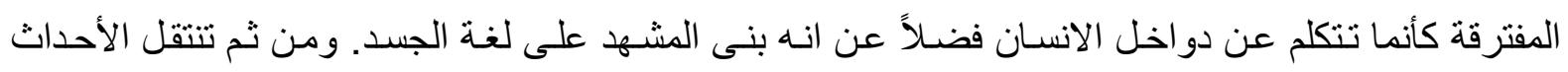

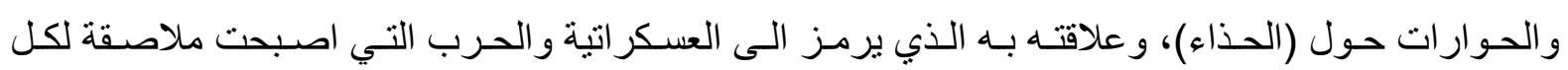
الإنسـانية التي تؤدي الى الدمار والموت، ومن ثم تدخل شخصيتي (بوزو)، وخلفه (لاكي) بمسير عسكري تر افقها كلمات (يمين، يسار) الى الأمام، ثم يتوقف الممثلون بتشكيلات جسدية دلالة على (العسكر اتية). ومن ثم يبدأ الحوار بين الثخصيات الأربعة عن سبب وجودهم على هذه الأرض التي تعود ملكيتها الى (بوزو) و هم بانتظار المنقذ، ومن ثم يقوم (لاكي) بحركات سريعة حول مالك الأرض (بوزو) ويقوم بتجهيز

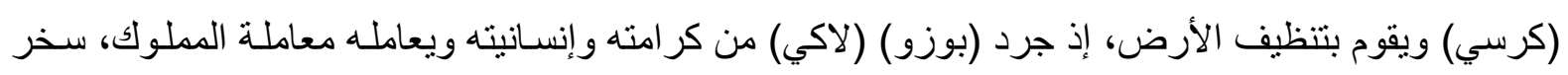
لاكي لخدمته. يظهـر (بـوزو) بمظهـر المتسـلط وسـيطرته التامسة على (لاكي) وهـو هنـا تشـبه بشخصـية (الجنـرال العسكري). و عن طريق حركة الأجساد وتعبير اتهم الإيمائية تظهر سبطرة (بوزو) وخضوع (لاكي)، وعن ونس طريق تدخين السيكار الذي يدخنه (بوزو) ثم بعطيهم السيكار ومن ثم يناولهم الواحد بعد الاخر ثم يعود السيكار الى (بوزو) الذي يقوم برميه على الأرض. جاءت اللغة مشحونة بالمعاني السالبة، تؤثر على أعصاب الانسان تدفعه نحو العدم او الرغبة في الموت

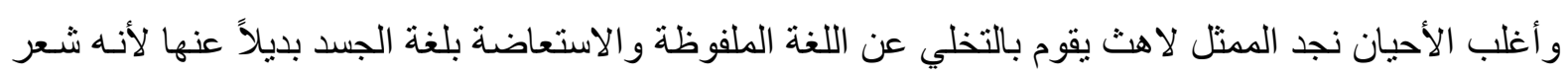
بالتهكم، ويشعر بعدمية وجوده مما بطلب الموت عنو اناً للخلاص و لا يطلب الحياة عنواناً للخلاص، وهو بهذا

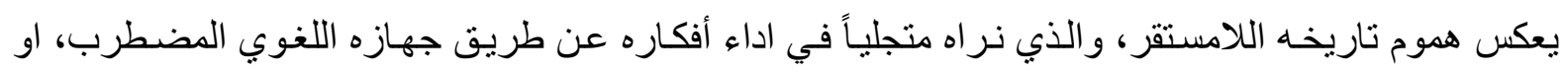
جهازه الجسدي المتهكم.

وحينما يجلس (لاكي) على الكرسي. يسحبه (بوزو) من تحته وفي الوقت نفسـه يقوم (بوزو) بسـب

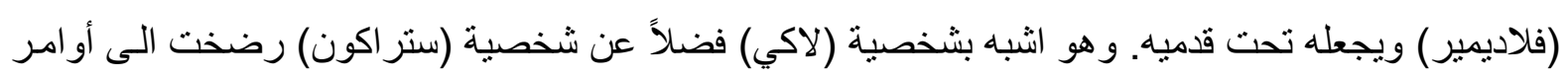
(بوزو) و ون طريق لبس قفاز (لاكي) بعد موته إذ جعل موت (لاكي) واقفاً مع حركة الر أس واليد، وهي إثـارة

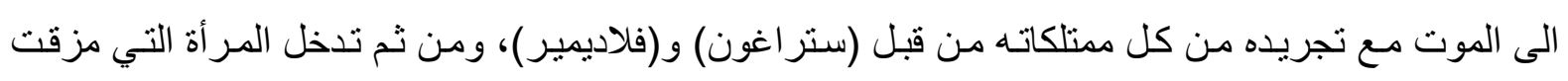
الكتاب، وهي حامل على وضع جنينها وعند عملية الولادة وهي تقف بجوار (لاكي) يظهر المولود ليس على

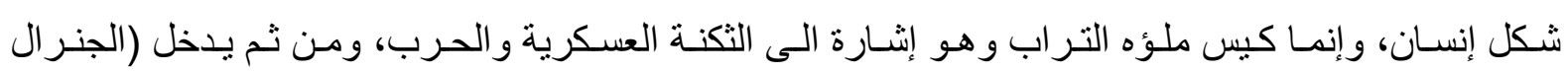
العسكري) و هو يتسول، ودخول كل من (بوزو)، و(فلاديمير)، و(ستر اغون) بمسير عسكري مع ترديد عبار ات

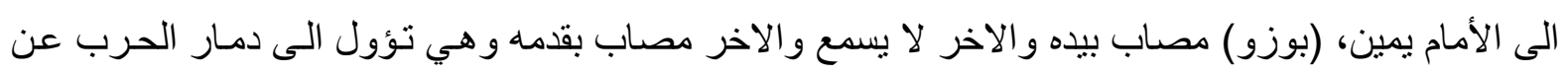
طريق تشكيلاته الجسدية للممثيلن وحركات ايديهم الى بشاعة الحرب و الدمار الذي يصيب البشرية من جر اءها. و لأن الهزائم ظلت لصيقة عبر التاريخ بالانسان العراقي، دفع الكثير من موارده سواء على مستوى

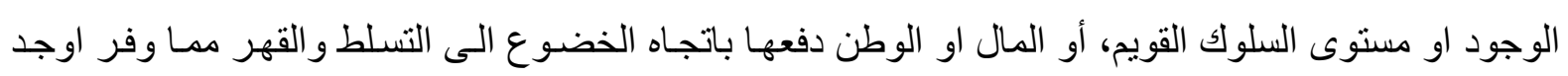


تر اتبـات في السياسـة فهنـاك الأعلى المتسلط وهنـاك الاسفل المقهور وهذه التراتبـات جعلت الانسـان العر اقي يخضع الى شروط الأنظمة الثمولية وتقبل مر اهقتها المرة ومن ثم تقبل نزو اتها الحربيـة المستمرة والتي دفع عمره ثمناً باهظاً لها، و هذا نجده في مستوى التعبير قد انعكس في الجانب الفني عن طريق العرض المسرحي عن طريق البحث عن المخلص في حين تعيش الثخصيات حالة من السلبية في المواجهة مما يدفع الأمل بإيجاد

غائب يعمل على تصحيح المعادلة وجعلها من معادلة يغلب فيها صاحب السلطة المتفرد الجموع المقهورة. ثم يبدأ الحوار بين (بوزو) و(لاكي) حول انتظار غودو، ومن ثم يتفق الجميع على انتظار المنقذوهي العودة الى بداية انتظار (غودو) الذي لا يأتي ابداً. وتتجلى هنا المشكلة اكثر حين نجد ان بوزو يقبل الانتظار وهو يمثل دور السيد اي دور السلطة ودور

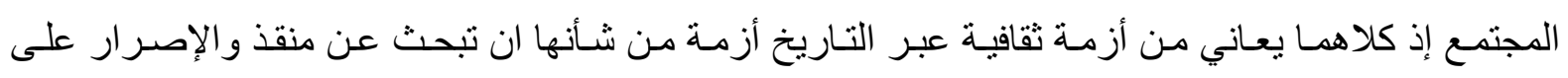
انتظـاره ومن دون الرغبـة في تجـاوز الموت والحرب عن طريق ادائهمـا وتغيير مستقبلها بإر ادتها لا بـإرادة المنقذ الغائب.

\section{النتائه والاستنتاجات}

النتائج ومناقشتها

ا - من خلال الصمت في الأداء عمل المخرج على تحويل ما هو مكتوب الى ما هو مسموع ومرئي ومحسوس ومؤثر في المنلقي.

ז- ان الصمت في الأداء يجعل اللامرئي مرئياً من خـلال دلالات واسعة تحمل معنى لدى المتلقي من خلال التأويل.

rـ ان عملية التلقي اللامرئي، تسهم في خلق التواصل بين الممثل و المتلقي من خلال الجدل الذي يثيره الصمت. عـ العرض المسـرحي منظومـة مـن العلامـات مـن خـلال فاعليـة اداء الجســ (الطاقـة) ومـا يبثنه مـن علامـات (موجـات). ممـا يعطي (ترددات) جماليـة تخلق حالـة مستقرة في العرض تفرض نفسـها وخاصـة في مسرح

النامعقول.

هـ التلقائية و التقنية في حركات جسد الممثل للأداء الصامت دليل على ثقافة الممثل وفهم عمله بشكل رصين. جـ الوعي في العملة الاخر اجية من قبل المخرج و استغلال ذلك الفضاء الواسع في كثف القدرة الادائية للمثثل.

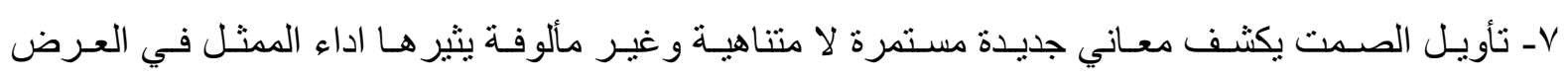
المسرحي. الاستنتاجات 1 الصمت لغة تعبيرية خاصة. 
r- استخدام الصمت في الأداء يخلق تأويل لدى المتلقي يبين ان للصمت جماليته تكمن في ان دلالته اكثر من

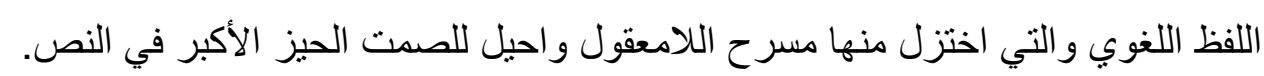
rـ تظهر من خلال الصمت قدرة الممثل الإبداعية في اعطاء الدلالة وكثف المعنى من خـلال تطويع جسده في الأداء.

عـ قدرة التأويلـ مـن قبـل المتلقي تعتمد على وعيـه وثقافته بالاضـافة الـى ذلك جماليـة الاداء الصـامت تجعل

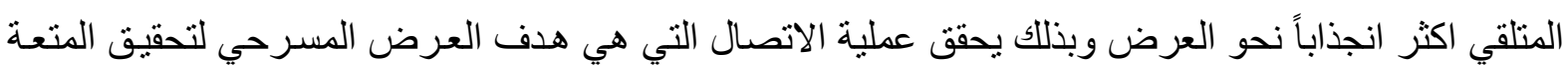
من خلال المعرفة. التوصيات

استحداث دروس البانتوميم وتطوير قابلية الجسد في مناهج كلية الفنون الجميلة. المقترحات در اسة الابعاد الفكرية و الجمالية لأداء الممثل في المسرح العر اقي. المسادر والهوامش

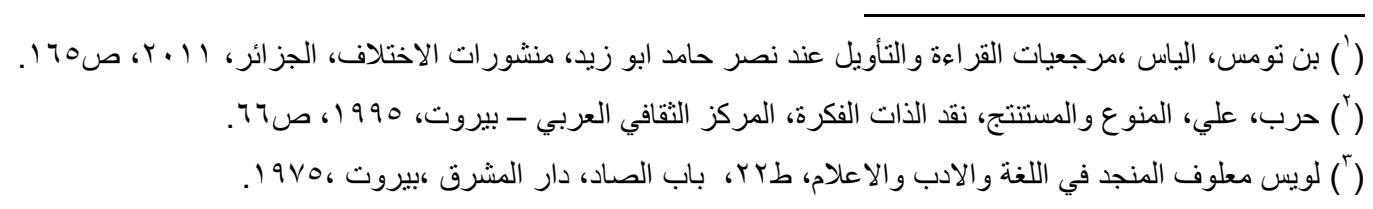

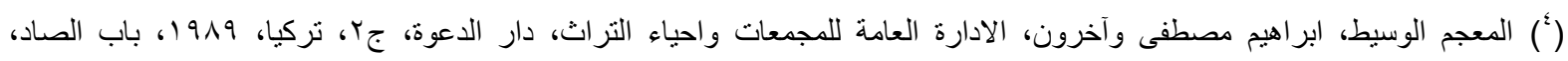
صA^ז.

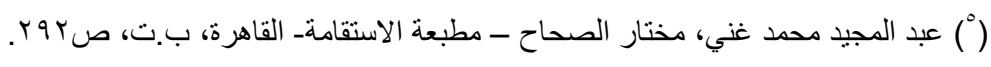

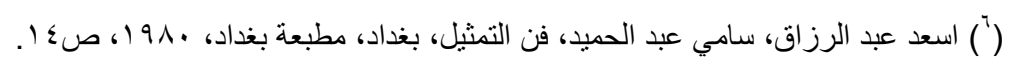

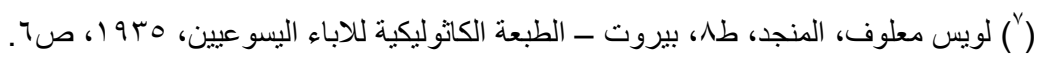

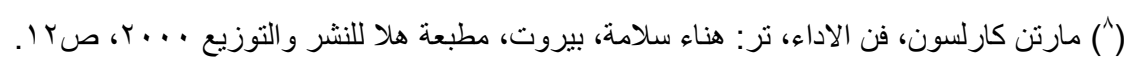

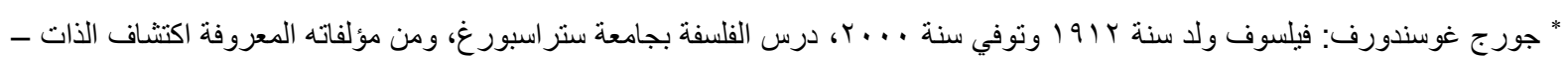

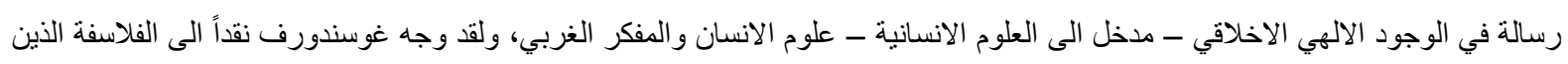

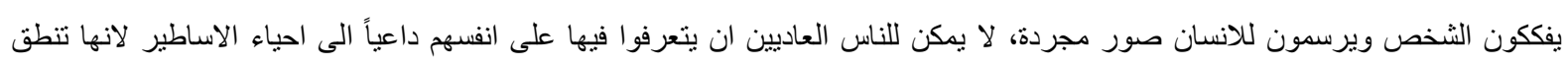

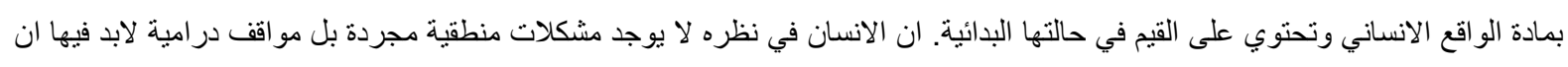

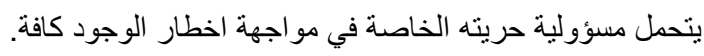
(') شرفي، عبد الكريم، من فلسفات التأويل الى نظريات القراءة، دراسة تحليلية نقدية في النظريات الحديثة، منشورات الاختلاف الجزائر،

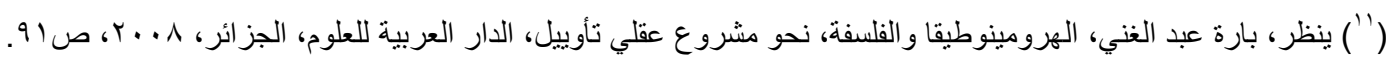

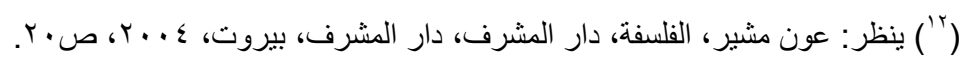

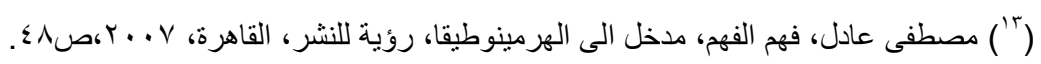

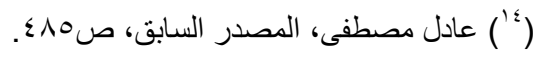

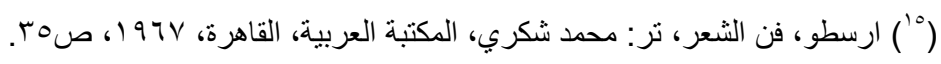

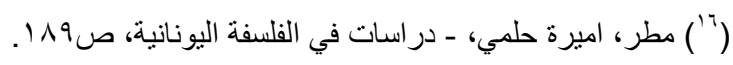

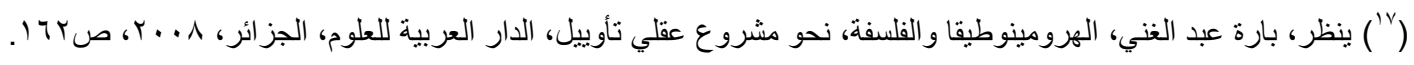


* راهب اغوطسين لاهوتي مفكر وكاتب بدأ في المانيا الاصلاح الديني (البروتستانتية) و الفصل عن الكنيسة في مسألة شأن الغفران وسلطة البابا و اكر ام القديس و القداس، نقل التور اة الى الالمانية فكانت الترجمة حدثاً دينياً و ادبياً.

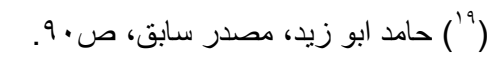

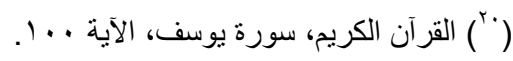

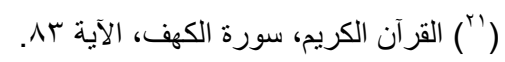

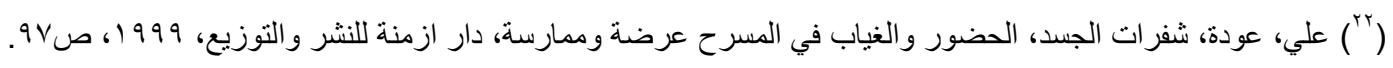

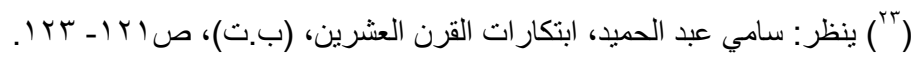

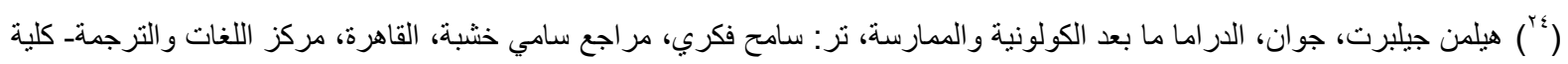

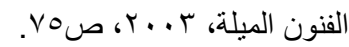

$$
\begin{aligned}
& \text { VOV ( }
\end{aligned}
$$

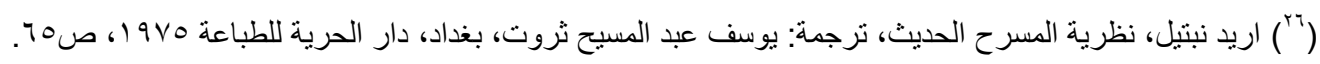

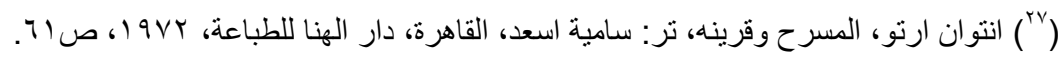

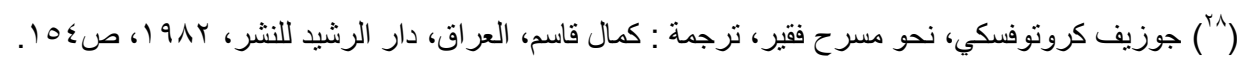

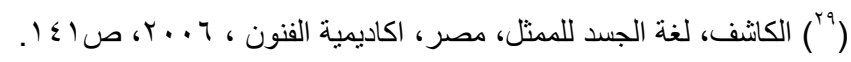

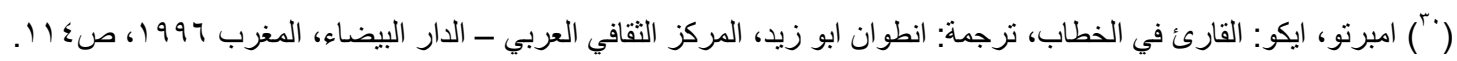

Research Summary

"Interpretation of Silence" is a recurring phenomenon in human beings as a language of expression of thoughts and of the human soul to the recipient through the actor on stage because the theater has direct discourse to the public and the delivery of ideas to them. This research answers the following question: To produce meaning for the recipient?)

The research included four chapters.

Chapter I: The methodological framework, which consists of: (the problem of research, its purpose, the limits of research, and the definition of terminology).

The second chapter deals with the theoretical framework. The research is divided into two sections:

The first topic (the concept of interpretation)

The second subject (silence technique of the representative)

The third chapter deals with research procedures and is divided into five sections: (research procedures, society, research sample, methodology, and research tool).

The fourth chapter was the results of the research, conclusions, recommendations and proposals.

The researcher concluded with a list of sources and references, and a summary in English 